\title{
Greening the Screen: An Environmental Challenge
}

\author{
Ekin Gündüz Özdemirci
}

Faculty of Communication, Beykent University, Ayazağa, Şişli/Istanbul 34398, Turkey; ekingunduz@gmail.com

Academic Editor: Adam Sweeting

Received: 8 October 2015; Accepted: 3 January 2016; Published: 3 June 2016

\begin{abstract}
Environmental themes and representations on screen are examined as a part of environmental social studies and can be considered a way of creating awareness of environmental issues. However, how often do we consider the environmental impact of a film or television shoot as an industrial process? In this article, I examine the sustainability practices in the motion picture industry and challenges to that by focusing on the British film and television industry as a case study. Using the interviews with industry representatives and some case studies, I discuss the possibilities of creating a change in behavior in the film industry, not only in terms of embedding green measures but also reconstituting industrial mechanisms on behalf of environmental sustainability.
\end{abstract}

Keywords: green filmmaking; environmental sustainability; justice to environment; ecocinema; ecomedia

\section{Introduction}

James E. Lovelock points out the importance of communication tools for the ecological movement in his book Gaia: A New Look at Life on Earth. They have not only a capacity to influence people through content but also by their technical capacity to spread information widely and rapidly ([1], p. 139). Looking at various media with an ecocritical approach is about focusing on the potential of communication tools for influencing our perception of nature. However, there is another aspect of the relationship between communication tools and the environment; it is the environmental impact of these tools even when they are operating as a facilitator for promoting ecological consciousness.

Environmental sustainability in the motion picture industry is an actual debate on many levels. Especially within developed film industries, making motion pictures contributes significantly to energy consumption and greenhouse emissions [2-5]. Developing sustainability departments in film and television companies and embedding best practices in a film production are a part of responsible and ethical business acts. ${ }^{1}$ However, in the business world, the term "sustainability" is primarily used to mean durable economic development that gives priority to business benefits, which are not always in line with environmental good. Sustainability definitely has a wider meaning that equally privileges the needs of human and non-human nature over any business benefits, regarding all levels of a business and the industrial process. In this essay, I argue that sustainable development cannot be possible until sustainability is embedded into the overarching industrial and economic regulations. This leads us to ask whether profitable businesses such the film and television industries can practice sustainability in the broader sense by balancing general business expectations with environmental well being, and if they are able to cover and prioritize essential environmental needs under current regulations.

1 According to the 2013 United Nations Global Compact-Accenture Chief Executive Officer (CEO) Study on Sustainability survey of 1000 global CEOs from 27 industries across 103 countries, 63\% of CEOs expect sustainability to transform their industry within five years even if they are constrained by market expectations ([6], pp. 11-12). Global companies such as Warner Bros, Universal Pictures or Sony Pictures put emphasis on the sustainable practices in their productions through specialized departments and customized web pages [7-9]. 
The United Nations World Commission on Environment and Development offered the common definition of sustainable development in 1987: "Sustainable development is development that meets the needs of the present without compromising the ability of future generations to meet their own needs." If we consider this definition in terms of the environment, we see an anthropocentric approach rather than an ecocentric one, which gives us an idea about the collective consciousness of how we conceive nature as separate from humankind. This conceptualization of nature among societies that position it as a separate operating system independent of human beings is another aspect of our discussion. Lovelock's Gaia Hypothesis can be considered as the first scientific theorization of the equality of all living and non-living components on earth, as he proposes that they all work together to promote life [1]. According to him, every organism has an equally significant contribution to the life supporting system that is present on earth. I will consider various environmental approaches embracing this idea of interrelatedness and emphasizing the importance of raising awareness of this among people. To that end, I argue that a form of ecological unconsciousness prevents people from taking full responsibility for environmental sustainability. The television and motion picture industries shall be my path into that discussion.

I begin by examining the carbon footprint of the British motion picture and television industry, as it has achieved a leading position in Europe and has already developed sustainability standards and a set of best practices that aim to minimize the ecological impact of filmmaking. We will examine more general environmental sustainability practices in the British film and television industry using face-to-face interviews with industry representatives and some case studies of sustainability practices that have been embedded in productions. The interviewees include sustainability managers of the British Film Institute (BFI) and the British Academy of Film and Television Arts (BAFTA), as well as representatives of their collaborating private and public entities who work to establish environmental best practices in the industry. These interviews will help us better understand the motivations and challenges in achieving environmental sustainability in the motion picture industry. From there, I will evaluate the proposed solutions to current challenges, the potential of ensuring environmental consciousness in the motion picture industry, and the environmental awareness among employees and audiences.

\section{The Carbon Footprint of the Film and Television Industries}

Most European countries have seen initiatives and campaigns to raise awareness of their carbon footprints; but we still do not have complete data on the environmental damage caused by many big industries. If all industrial carbon footprints were fully declared we would no doubt see that the problem goes far beyond the personal level and requires a solution beyond domestic recycling.

The University of California, Los Angeles (UCLA) report Sustainability in the Motion Picture Industry (2006) can be considered the first detailed work on the environmental damage of the film and television industry. The report focuses on the carbon footprint of the motion picture industry in the Los Angeles area and compares it with other industries present in the region. The authors of the report, Charles Corbett and Richard Turco, adopt a broad view of sustainability by including measures of human well being other than purely environmental ones. Rather than the more common phrase "carbon footprint", they use the term "environmental footprint" to consider components such as conventional pollutants, energy use, greenhouse gas emissions, hazardous waste, and fatalities associated with different industries. "Ecological footprint" is another useful measurement system that calculates the environmental impact within a specific area of land occupied by measuring components such as bioproductive potential, the types of fuels used, and the raw materials obtained [10]. In this essay, however, I use term "carbon footprint" as it is considered as a general measure of our overall contribution to global warming ([11], p. 29). A carbon footprint measures the total greenhouse gas emissions in tonnes of carbon dioxide equivalent, which allows the different greenhouse gases to be compared on a like-for-like basis relative to one unit of $\mathrm{CO}_{2}$ [12]. 
According to the UCLA report, the motion picture industry is the largest contributor to conventional air pollution within the Los Angeles metropolitan area, creating more pollution than sectors such as aerospace, hotels, apparel and semiconductor manufacturing ([2], p. 10). The energy consumption and greenhouse emissions of the motion picture industry also come close to the aerospace and apparel industries ([2], p. 12). Indeed, the overall environmental costs of American media production is made manifest in a report by the Political Economy Research Institute entitled "Misfortune 100: Top Corporate Air Polluters in the United States", which shamed media owners by placing them at Numbers 1, 3, 16, 22 and 39 on the list ([13], p. 2).

The British Film Institute's (BFI) Research and Statistics Unit estimate that the annual carbon footprint for UK film production might be 149,760 tonnes [5]. A tonne of carbon dioxide equivalent is approximately equal to 2160 miles driven by an average passenger vehicle [14]. According to Melanie Dicks, a producer and sustainability consultant at London-based company Greenshoot, a blockbuster film, one that is lavishly produced and has wide popularity, emits between 2500 and 3500 tonnes of carbon; a more modest film with eight to 10 weeks' shooting produces between 500 and 750 tonnes while a typical low budget film with approximately four weeks' shooting can emit about 100-250 tonnes [15]. Year three report of the BAFTA Albert Consortium, a collaborative body of UK's leading production companies and broadcasters to develop sustainability in the industry shows that, in 2014, the average carbon footprint of a television program was 9.4 tonnes per hour of broadcast time.

To be sure, these figures are low compared to other sectors of the economy. According to figures for 2013 [Figure 1], the energy supply, water and waste sectors are responsible for the highest carbon emissions in the UK, while the art and entertainment sector, which includes the motion picture industry, is among the sectors with the lowest greenhouse emissions ([16], p. 6). However, even if these statistics examine sectors separately, all industries should be considered as a whole in terms of environmental sustainability because they share resources and services. For example, the motion picture industry contributes to the carbon emissions of the energy supply, water and waste sectors.

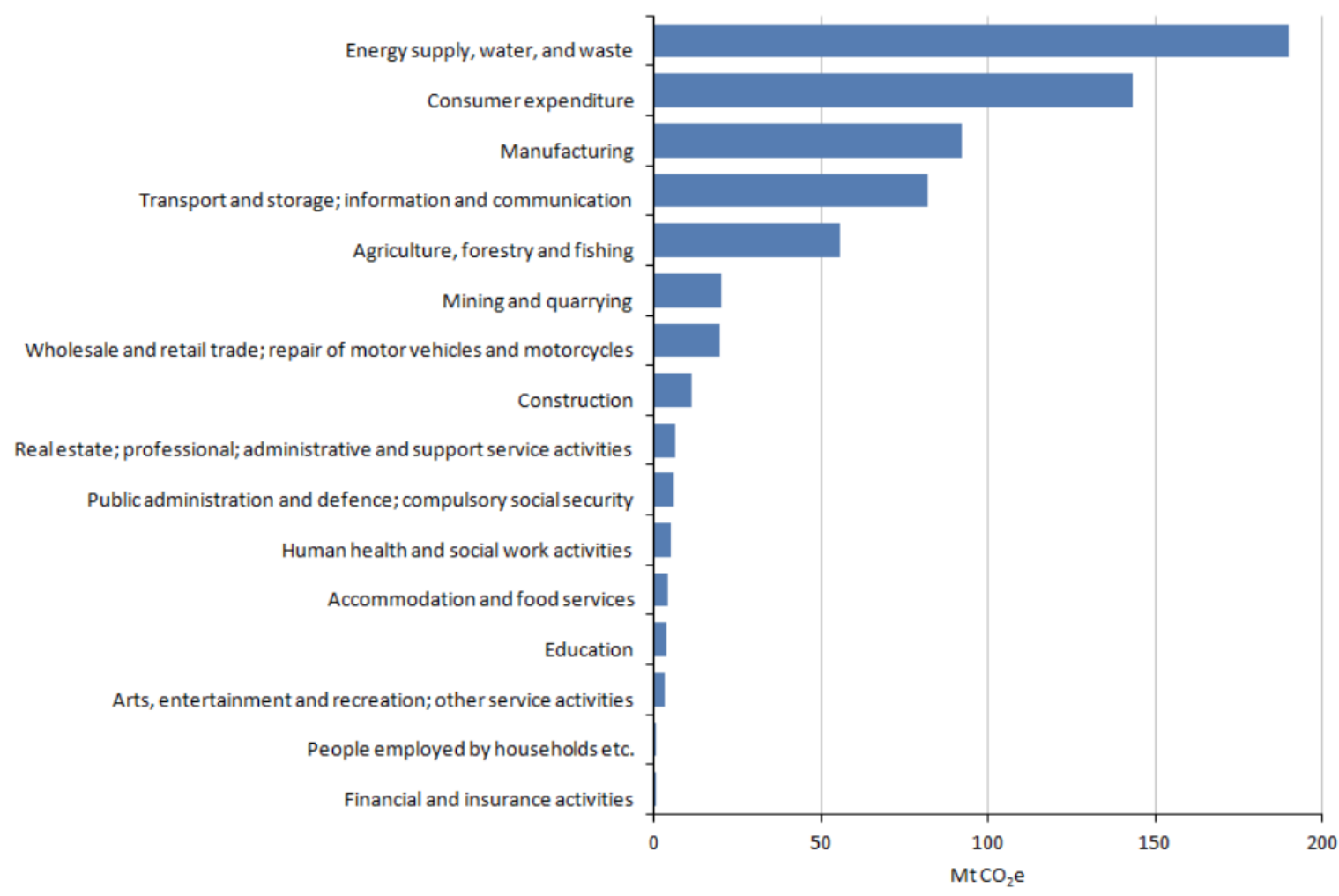

Figure 1. Greenhouse gas emissions by economic sector, 2013. UK residency basis. (Source: Ricardo-AEA, Office for National Statistics). 
The contributors of carbon emissions in a film production can vary. They may be electricity, physical materials, fuel, or food waste. One might think that energy usage would be the most significant element in creating a carbon footprint, but that can change according to the quality of shooting and technical conditions in filmmaking. For example, it is now possible to decrease emissions from the grid compared to older lighting technologies by employing more innovative low energy lighting (LEL) solutions. ${ }^{2}$ However, a studio shooting for a period film that requires a large amount of physical material might have higher emissions associated with construction than for energy consumption, depending on the materials used in set construction such as metal, timber, medium density fibreboard (MDF) and plastic. Not all films are produced alike, but everybody travels to get to the set. Moreover, set and equipment transportation can cause significant carbon emissions. In addition, the diesel generators that are commonly used in outdoor shoots also emit carbon if they are not powered by non-carbon-based alternative energy. Everybody on a film set also eats, so food waste that does not go to composting or recycling can contribute to methane gas emissions from landfills. ${ }^{3}$

The Department for Environment, Food and Rural Affairs' (DEFRA) "waste hierarchy" ranks waste management options according to what is best for the environment ([19], p. 3). It gives priority to reducing waste in the first place and then to preparing it for reuse before the recycling option. According to some studies on environmental justice, green movements should deal with reducing waste production at the source instead of regulating waste disposal ([20], p. 49). Greening practices in the British film and television industry vary, but according to our interviews and the case studies made by the BAFTA, BFI and Greenshoot, most common practices seem to be related to recycling; however, reducing waste and energy or fuel use during the whole production process is still not very common in practice. ${ }^{4}$

\section{Environmental Sustainability Practices in the British Film and Television Industry}

In the UK, there is a promising collaboration between the film and television industries, led by the BFI and BAFTA, for developing environmental best practices, but for now this collaboration is limited to organizing meetings and sharing reports.

Environmentally friendly practices in the British television industry started with the creation of the Albert Consortium in 2011. Albert is a carbon calculator for on-screen productions that was developed and piloted in-house at the BBC in 2010. The BBC shared Albert with the industry through a partnership hosted by BAFTA. Currently, the BAFTA Albert Consortium creates a space for partners like BBC, ITELEVISION, SKY and Channel 4 to set the direction for the rest of the industry.

There is strong collaboration and industry support for environmental sustainability within the British television industry with a growing consortium that has increased its membership by $20 \%$ on a year-by-year basis ([4], p. 3). The Albert Consortium aims to raise program makers' awareness of environmental sustainability issues and educate them about taking certain actions when filming. It highlights to production companies and broadcasters the environmental impact of their actions. Albert is designed as a tool to be used by producers and production managers, because there is a common agreement in the industry that the decision making and tracking of environmental sustainability should come from the top. Therefore, the tool is composed of questions that program makers can answer, such as the amount of money spent on certain suppliers and materials. It shows the carbon footprint of a production in tonnes per hour of output and the equivalent of that in terms of

2 Low Energy Lighting (LEL) solution is the combination of efficient lighting equipment, design and management. It will reduce energy consumption, cooling requirements and reduce the frequency of lamp replacement ([17], p. 4). According to the BBC Arup Low Energy Lighting Guide for Television Productions, LEL options can save at least 75\% of the energy consumed by traditional lighting such as tungsten softlights with comparable effects ([17], p. 23).

3 In landfills, organic materials, like food scraps and yard trimmings, are broken down by bacteria to produce methane. Methane, a potent greenhouse gas, has been shown to have a warming potential of 21 times that of carbon dioxide [18].

4 For some case studies of sustainable practices in the British film and TV industry, see: [21]. 
the average carbon emissions in the UK per year so that it can clarify the environmental impact of a program for the users.

However, the film producers typically do not use the Albert carbon calculator, despite it being made free to the industry. Rather, private consultants are used instead. Film producers or production managers do not usually deal with sustainability management themselves; it is more common to hire a consultant. Greenshoot, for example, is a private environmental and sustainability consultancy company that has its own carbon calculator called START (Sustainability Tracking Asset Repurposing Tools) that they developed with an independent energy consultant company [15]. As one of my interviewees stated, the bigger the production, the more you have got to manage, and it can be a big task for somebody to undertake [22]. For these reasons and more, the film industry typically employs outside consultants to mange its sustainability practices.

The BFI announced its aim to have a leading position in the British film industry by signing a sustainability policy in 2012. It encourages film productions to embed sustainable practices in their processes by supporting case studies and the training of film crew in collaboration with private consultancies. ${ }^{5}$ The starting point of the sustainability agenda for the British film industry was the British Standard 8909 created in 2011 by an initiative of the UK Film Council. This standard specifies requirements for a sustainability management system for film. BS 8909 addresses sustainability in a broad sense, including economic and social aspects such as the contribution to diversity, stability of the local economy, ethical business practices, community relations, fair wages and child labor. If a production wants to be BS 8909 compliant, it has to apply all of these policies. As it has a very broad scope, most of the companies in the film industry choose to incorporate environmental sustainability practices separately instead of embedding the standard as a whole in their processes. According to Melanie Dicks of Greenshoot, there are about 800 production companies in London and only around $2 \%$ practice sustainability management; any increase in that percentage will depends on legislative regulations such as sanctions or incentives that benefit the environment [15].

In both the film and television industries, sustainability practices depend on voluntary action and are not yet highly embedded. The BFI aims to embed sustainability in the film industry in a broader sense in the future. However, so far, it is in a position to reduce the environmental impact of the film industry through mentoring. It shares information and ideas on green filmmaking and organizes discussions with the film industry through panels and conferences. However, it is in the process of developing some regulations such as adding a new criterion for sustainability to its funding conditions that would encourage more companies to take action.

There are currently 220 television production companies who signed up to use Albert [24]. Among these companies, only SKY has made Albert mandatory for its programs. In order to sell a production to SKY, producers must meet certain criteria, one of which is that the show's carbon footprint has to be measured by Albert. Except for SKY, however, using Albert remains optional in the industry. The BBC says that they expect to make Albert obligatory at some point [22]. But as of now, they use Albert as a voluntary program for producers so as not to overload production companies with new mandates.

Recently, the television industry developed a new plan-Albert+ - to give a clearer set of instructions on how to reduce a production's carbon footprint out of concern that producers were not taking action to reduce their footprint after measuring their activities with the Albert carbon calculator. Albert+ also offers a reward system. There are three levels (One, Two or Three Star) of Albert+ certification as measured by the range and complexity of green practices during each production. The new system was piloted by the BBC 2014 with at least 10 programs such as Trollies, Springwatch or Invictus Games that now display the Albert+ logo on their end credits. Their best practices include cutting stage power needs, sourcing pre-used set dressings, helping feed local livestock with surplus

5 Green Production Training is a program carried out by Greenshoot in partnership with Screen South and Creative Skillset, funded by the National Lottery via the BFI, and through the Skills Investment Fund (SIF). For more information: [23]. 
fresh produce, carpooling and using low carbon generators ([4], p. 7). In the coming years, the BBC expects to expand the Albert+ certificate system to all other broadcasters and production companies working with the BAFTA Albert Consortium [22].

\section{Steps towards Better Practices in Film and Television}

For sustainability practices to be coherent and fully embedded throughout film and television production the entire pre-production process must be considered, including a full analysis of the script before shooting begins. There are many issues and practices to consider. As an example, the use of MDF as a set building material raises important concerns for those interested in sustainable film production [25]. First of all, it does not break down easily nor can it be recycled. There are also concerns that its fibers and dust compromise human health and may even be carcinogenic depending on the formaldehyde levels of the product. Formaldehyde is classified in the UK, and in the European Union as a carcinogen and it carries the hazard statement "suspected of causing cancer" [26]. Instead of using MDF, sustainable set recycling companies encourage the use of recyclable wood that can be regrown and reused [25].

After a film shooting, the sets are smashed up and put into skips that are sent off to general landfill [27]. Recycling or upcycling are the sustainable alternatives of dealing with set waste. In that case, materials such as metal or timber are separated and sent to recycling stations. However, many materials, props and set pieces, such as the windows, doors, electrical components, hanging irons, and casters, can be used again and upcycled by the industry as opposed to purely recycling them. Some British companies such as Scenery Salvage collect useful props, costumes and set pieces for second hand usage or repurposing [27]. Reuse of old props and sets instead of buying new ones is also a sustainable practice that can reduce the carbon footprint of a film production.

Other best practices to reduce carbon in a film production include using energy efficient lighting and generators, using less paper, hiring local crew to lower emissions from transport and accommodation, having local and seasonal food to reduce food miles and imports, and, if the food is imported, at least paying attention to fair trade and organic options.

Though controversial, another potential common practice is offsetting, by which a production company can retire the carbon in a set by giving money to plant some trees or apply a best practice in some other component of the production to offset the carbon emitted during set construction. In terms of waste hierarchy, however, this practice may be near the bottom, as the amount of waste remains stable. Others have critiqued offsetting for its presumed lack of scientific legitimacy stemming from the inherent uncertainty of calculating the carbon footprint of particular activities (such as set building) or the moral complications of discharging environmental duties by pricing carbon [28-30].

\section{Motivations and Challenges}

Applying best practices for reducing the carbon footprint of a film production requires changing the habits of individual people and the industry in general. According to the interviews undertaken for this project, however, the motivations and incentives for changing habits in the industry vary. That said, self-engagement creates an ethical motivation and can encourage people to take action for environmental good. Interviewees mostly believe that environmental consciousness is something that people can embrace easily when explained.

Financial expectations can be an incentive since applying sustainable practices helps companies save money in many ways. As an example, landfill carries a very high tax in the UK, with a price of $£ 140$ a tonne. The set recycling company Scenery Salvage, on the other hand, charges $£ 75$ a tonne for their service because they recycle or upcycle $95 \%$ of sets while only $5 \%$ goes to landfill [27]. The sustainability consultancy company Greenshoot offers another example from a film shoot where they managed to reduce the waste budget from $£ 350$ a week to $£ 60$ [15]. Some sustainable practices like LED lights, setting up accounts with green taxi services or installing solar panels for energy are also longer-term investments that would lower production costs in time. 
An analysis using the Morgan Stanley Capital International World Index shows that companies that improved their sustainability performance between 2006 and 2008 financially out-performed their peers in the next two years by more than 11\% [31]. In their UCLA study, Corbett and Turco also indicate that the best environmental practices turn out to be economically beneficial as they lead to savings in cost or often, and more importantly, time ([2], p. 3). However, in the same report, one of the interviewees mentions that cost savings might have to be as high as $\$ 100,000-200,000$ for a larger production to actually change its behavior ([2], p. 23). As the scale of the production gets bigger, the expectations of cost saving become higher as well.

Environmental sustainability can be a marketing tool, so reputational benefit is another motivation for the production companies and broadcasters. My interviewees believe that environmental practices will bring the productions recognition among peers and also among audiences in the future. That might create a public awareness of environmental issues and also put pressure on more production companies to apply best practices.

Applying good practices for environmental sustainability is still not a completely mainstream activity in the British film and television industry. Aaron Matthews, the sustainability manager of BAFTA, admits that the industry is still celebrating some really small successes like people not using disposable water bottles and printing on double-sided paper [24].

In specific areas, the technology and the suppliers are not yet as well developed as they need to be to provide the productions what they need. For instance, low carbon technologies such as solar power or waste vegetable oil that can be used in specially conditioned generators to replace diesel are not widely used in the industry as few of the major suppliers can currently provide them [22]. So, that means you would have to buy an additional service alongside the standard kit that you are already hiring in, which obviously costs more. Another challenge for the British film and television industry is that the suppliers are mostly based in the South of England, so even if you wanted to use alternative energies to replace a diesel generator on a set, the potential for carbon emissions linked to transport increases if you want to make a film in, for example, Scotland [22].

Another challenge is the general structure of the film industry. Squeezed pre-production timeframes might not be adequate most of the time for making decisions that will change habits in terms of suppliers and production practices. This is similar to what Corbett and Turco mention in their report on Los Angeles, that there is "waste caused by fear" in the film industry. A lot of last minute changes make it difficult to establish a budget for waste management planning, which in turn causes more waste ([2], pp. 34-35). My interviewees also mentioned that the large number of freelance workers present challenges for those hoping to embed sustainability initiatives more widely in the industry. Corbett and Turco come to similar conclusions in their report, saying that the highly decentralized nature of the film industry, with its focus on short-term, ever-changing production teams rather than long-term physical supply chains, stands in the way of the industry adopting many of the environmental programs that are common in more traditional industries ([2], p. 3).

The situation seems quite different in the television industry because television programs are more scheduled and stable in terms of content. This obviously allows more time and practice for planning environmental sustainability. At the same time, the scale of television production is generally smaller than film production, which makes it easier to incorporate or make a decision to experiment with some green practices such as using waste vegetable oil in generators or using solar power for the whole shoot. Such factors help explain why the overall standard of best practices seems higher, and the collaborative commitment to embed them is stronger in television than it is in the film industry.

In the end, environmental sustainability in the British film and television industry remains a voluntary practice that depends on one's sense of moral imperatives rather than particular financial or legislative imperatives. If people in the industry have circles of professionals that they work with, they will want to keep working with those people. According to Melanie Dicks from Greenshoot, the reaction of the film industry about a change in general can be, "If it is not broken why fix it? Why should we do anything?" [15]. 


\section{Proposed Solutions}

Green leaders in the film and television industry have proposed some solutions and prospective actions to take to enhance sustainability. There is a common opinion in support of the necessity for governmental action. There is work underway to make British Standard 8909 an international standard, which might eventually become a legitimate requirement for the whole industry. On the other hand, the BFI has an agenda for including sustainability criteria in the National Film Fund and formally demanding the industry to participate in best practices. Other ideas that have been mentioned include developing a new green film fund and green award system in the UK [15,32].

Leadership remains an important element, as all interviewees believe that decision making about embedding environmental sustainability should be regulated at the managerial level. At the same time, staff commitment is considered another requirement that can be achieved by educating and motivating the staff. Along these lines, the BAFTA Albert Consortium organizes trainings such as "Carbon Literacy for Broadcast Media" that have been devised through a partnership with several media outlets to instruct the industry about green program making ([4], p. 8).

Martin Kern from Scenery Salvage thinks that educating film students, who represent the future of the industry, is also an efficient way to create a change in behavior in the long term [27]. For instance, Scenery Salvage works with some film and art schools by providing them used materials and props for their projects and giving seminars on set recycling [27]. Besides the staff and students, creating awareness among audiences is another effective way of promoting good environmental practice in the industry because audiences could become demanding as they become aware that the media that they enjoy has an environmental impact.

The current digital direction of the current film industry is sometimes considered a development that might help filmmaking become more environmentally sustainable. Sony Pictures, for example, has declared the transition from physical to digital production and distribution as one of its environmental goals [33]. Brad Stewart, a communications executive and columnist on social media and green marketing, sees digitalization as a hope for a greener film industry and claims that the industry could expand by moving to a more pervasive distribution model and maintaining a low carbon footprint with a reduction in transport and material costs [34]. Similarly, the ecocritics Robin Murray and Joseph Heumann mention that Slumdog Millionaire and Avatar's digital production represent large steps towards the "greening" of Hollywood ([35], p. 187).

The recording, post-production, and distribution process in the film and television industry have become ever-more digitized, so distribution costs and carbon emissions from transportation and the production of film can be significantly reduced. Murray and Heumann argue that the transition to digital ends the chemical links of producing film prints, eliminates the need to create and deliver thousands of prints for exhibition, and obviates the need to destroy the prints after their theatrical runs ([35], p. 187).

Aside from relying on toxic chemicals, the process of manufacturing film print for photography and motion pictures also depends on the meat industry, an industry that itself carries a big carbon footprint and requires a supply of water. ${ }^{6}$ The light-sensitive silver salts that create a visible image when exposed to light are suspended in a thin layer of gelatin, one of the chief ingredients of which is collagen that is produced by boiling the bones and tissues of animals ([37], p. 18). At the end of the century, Kodak supplied $80 \%$ of the world's film stock and was using 35-53 million gallons of fresh water a day for this process; since the 1970s, most of the wastewater had been collected in a treatment plant in order to comply with America's Clean Water Act ([13], p. 73). On the other hand, the amount of waste from the manufacturing of film is high considering that only about 10 million pounds of film

6 According to the report of the Food and Agriculture Organization of the United Nations, the international meat industry generates roughly $15 \%$ of the world's greenhouse gas emissions [36]. 
stock, of the 35 million pounds created annually, is recycled in the Los Angeles area that represents the heart of the industry ([2], p. 25).

However, we still do not know the full environmental impact of digital processes compared to traditional filmmaking. There are no certain figures yet, but for instance editing requires large amounts of energy as shoots can take longer now thanks to new technologies, which means more time spent editing, hence more energy. ${ }^{7}$ One interviewee claims that once renewable energy can be adopted on a larger scale then we can talk about a greener industry with digitalization [24].

The fact that technology changes so quickly leads to excess waste. In 2007, the US Environmental Protection Agency (EPA) reported that "of the 2.25 million tons of televisions, cell phones and computer products ready for end-of-life management, 18\% (414,000 tons) was collected for recycling and $82 \%$ (1.84 million tons) was disposed of, primarily in landfill" ([13], p. 3). Similarly, Richard Maxwell and Toby Miller have called attention to the process by which electronic waste is destroyed in order to collect valuable metals such as gold, silver or copper, and how this process, in turn, creates serious health risks to bones, brains, stomachs, lungs, as well as potential birth defects and disrupted biological development in children ([13], p. 3).

\section{Conclusions}

Timothy Luke, professor for environmental politics and cultural studies, poses important that the concept of sustainability: "Sustainable under what conditions?" or "Sustainable at what level of human appropriation?" ([39], pp. 21-22). It is vital that we recognize that all actions have interrelated environmental impacts. This view resembles the physicist Fritjof Capra's holistic vision that acknowledges the interdependence of all physical, biological, social and cultural elements ([40], p. 265). In the case of the motion picture industry, we might ask: is it sustainable at the level of pre-production, production, post-production and distribution processes, including launch events, by-products, global marketing and screenings, within the overall process of a growth economy? Unfortunately, when we consider the business perception of sustainability that gives priority to profits, it is hard to say that crucial aspects of human and non-human nature are current priorities on all levels of the motion picture industry.

Our current model of business as usual in making profit from blockbusters-with their associated consumer by-products, international festivals, and global distribution networks-challenges sustainability and ultimately lowers the level of these industries as measured by the waste hierarchy. As one interviewee said, finance and carbon dioxide are so tightly linked that when you have an expensive production and all its associated outcomes, a big environmental impact is almost inevitable. Unless a change towards more environmentally friendly options in overall business activities is achieved, investing in sustainability departments by big studios will remain a mere marketing practice-in a sense, a green washing act.

By way of example, David Ingram points out the contradictory position of The Disney Company in terms of environmental and social aspects of sustainability. Despite being one of the founders of Environmental Media Association (EMA), an organization that espouses green practices and promotes environmental issues in Hollywood movies, Disney was accused of labor abuses in its licensed garment manufacturing factories in Haiti by the National Labor Committee, now the Institute for Global Labor and Human Rights ([41], p. 21). Ingram also mentions Disney's campaign of product franchising for the "environmentalist" movie The Lion King in collaboration with large multinational corporations such Burger King, Mattel, Kodak, and Nestlé, thus highlighting a contradiction with the deep ecological rhetoric of the film ([41], p. 24).

Is it a solution to produce fewer films or television programs? Probably the real problem is not the amount of productions but the way we produce them and the way that the industry operates 
within current economic and industrial regulations. These models depend on a strong anthropocentric approach such as the popular definition of sustainable development. As Vandana Shiva says, it is all-too-common to make decisions about resource use according to market rules and not to nature's limits, a habit that leads to the separation of "ecology from economy" ([42], p. 15).

Current practices applied in the motion picture industry at the level of companies and establishments do not seem sufficient to embed environmental sustainability in a broader sense. As mentioned in the interviews, there is an important need to transform environmental best practices from being only voluntary initiatives into legislative and financial imperatives. For instance, fulfilling the expectation of achieving cost savings through best practices, especially for big budget productions that have a higher environmental impact, seems possible by making environmentally friendly services more advantageous and preferable with financial privileges. At a governmental level, this can be regulated by legislation that includes tax breaks for sustainable products and services such as energy efficient lighting or solar energy, as well as high taxes on unsustainable products and materials such as MDF or fossil fuel. The increased landfill tax in the UK offers a good example of that approach. ${ }^{8}$ Herman Daly proposes limits to throughput as one of the institutional changes that can be made. This would require the "government setting aggregate depletion quotas on each basic resource and auctioning off the quota rights to individuals and firms" ([44], pp. 98-99). James O'Connor also says that national budgets could assign high taxes to raw material inputs (e.g., coal, oil, nitrogen) and certain outputs (e.g., gasoline, chemical building blocks), meanwhile placing value added taxes on a wide range of environmentally unfriendly consumer products (cars, plastic products, throwaway cans) ([45], p. 237).

On the other hand, interviews and previous research highlight that the development of environmental sustainability in the film industry is strongly linked to issues related to the industry's general structure and working conditions. Industrial barriers such as people working on a freelance basis, squeezed production times or last minute changes that restrict the efficient application of environmental best practices should be resolved. In that sense, there is need for a general reconstitution in the film industry by considering sustainability as a whole, including social and economic aspects with support of regulations such as BS 8909.

We know that individuals are most likely to take action only after they have attained new levels of ethical engagement toward the environment. But they must be self-engaged. Unfortunately, "If it is not broken why fix it?" is a common reaction in the film industry in case of a change towards environmental sustainability, and this approach is related to the current ecological unconsciousness among societies that ignore the interconnectedness of all organisms on earth and interrelated environmental impacts of different business acts. Ecological consciousness can extend from societies to industry and place pressure on protecting the environment, but a reverse contribution is also possible.

At the Greening the Screen conference in January 2015, a conference jointly organized by BAFTA and the BFI to unite the green leaders within the British film and television industry, one of the participants highlighted the "need to see sustainability like diversity." Diversity has for several years been a regulated issue in the British film and television industry; environmental sustainability should be addressed in the same way. ${ }^{9}$ This idea should be expanded to the extent that we embed environmental sustainability as an obligation along with health and safety issues within an industry.

Vandana Shiva draws attention to "justice to the environment" and uses the term "earth democracy", a term that involves a concern not only for the fate and well-being of all humans but for all beings on earth ([42], p. 4). Earth democracy requires a reconsideration of our priorities and redefinition of human needs and wants in balance with the needs of non-human nature. Similarly, Arne Naess, who introduced the term "deep ecology" as a clear ecocentric perspective for the environmental

\footnotetext{
For more about increased landfill tax rates, see [43].

A new act introduced in 2003 by the Office of Communications that regulates the UK media is in favor of ownership diversity and media pluralism, and restricts cross-media dominance [46].
} 
movement [47], proposes "ecosophy" to define a philosophy inspired by the deep ecological movement. According to Naess, the suffix "sophy" highlights a modest realization of wisdom rather than science or information ([48], p. 258). In his view, ecosophy promotes a "strong identification with the whole of nature in its diversity and interdependence of parts" ([48], p. 259). Lovelock's ideas scientifically support this environmental philosophy encouraging people to remember that they are not superior to, but a part of nature. However, despite the existence of indigenous communities still living with such consciousness, the Western world only started to talk about this idea of interrelatedness in the late 70s, and Lovelock's hypothesis was only enshrined as a theory recently. This clearly manifests the need to find effective tools to change our Western perspectives of nature in the first place. As Richard Maxwell and Toby Miller state, this is about moving from "green consumption" to "green citizenship" ([13], p. 31).

In parallel with Lovelock's argument that "life is an agent in its own survival" [49], Joseph W. Meeker points out that the earth's predicament is not a disease to be cured but a condition to be lived with and stresses the requirement of a new philosophy comprised of a new arrangement of thoughts, feelings and actions ([50], p. 251). Legislative actions such as tax and industrial regulations are important and needed; however, a permanent solution for establishing sustainability in industries can only be possible through a shift in our system of values, which would encourage a business that, with O'Connor's words, "preserve, defend and enhance the conditions of life and life itself" ([45], p. 316).

Even though further actions are required, current green initiatives in film and television are still very important steps for raising environmental awareness within the industry, and also among audiences. However, environmental sustainability cannot be fully achieved until we start to think about it within the bigger picture, in other words, beyond the limited levels of the film or television production process. Being "aware of the host of contemporary environmental problems" does not always mean that we "see them as interrelated" ([51], p. 29). No matter how large the investments made in a sustainability department of a big film studio are, or how much set waste is reduced by recycling or reuse, the film and television industries will always have a serious environmental impact as long as they continue their current practices within the entire industrial process.

Acknowledgments: This research was conducted with the consultancy of David Ingram at Brunel University, UK and supported by a grant from The Scientific and Technological Research Council of Turkey (TUBITAK).

Conflicts of Interest: The author declares no conflict of interest.

\section{References}

1. James Lovelock. Gaia: A New Look at Life on Earth. Oxford: Oxford University Press, 1979.

2. Charles J. Corbett, and Richard P. Turco. "Sustainability in the Motion Picture Industry." University of California Los Angeles (UCLA), 2006. Available online: http://www.environment.ucla.edu/perch/resources/ mpisreport.pdf (accessed on 13 January 2015).

3. BAFTA Albert Consortium. "Year One Report." 2012. Available online: http://static.bafta.org/files/albertyear-one-report-carbon-footprinting-the-television-industry-1574.pdf (accessed on 10 May 2015).

4. BAFTA Albert Consortium. "Year Three Report." 2015. Available online: http://m.mediagreenhouse.co.uk/ 01131/0193/albertReport2014_02.pdf (accessed on 10 May 2015).

5. Greeningfilm. "A Carbon Footprint for the UK Film Industry." Available online: http:/ /www.greeningfilm. com/a-carbon-footprint-for-uk-film-industry (accessed on 16 March 2015).

6. United Nations Global Compact. "Accenture CEO Study on Sustainability." 2013. Available online: https://acnprod.accenture.com/ /media/Accenture/ConversionAssets/DotCom/Documents/Global/ PDF/Strategy_5/Accenture-UN-Global-Compact-Acn-CEO-Study-Sustainability-2013.pdf (accessed on 12 May 2015).

7. Sony Pictures. "A Greener World." Available online: http://www.sonypictures.com/green/ (accessed on 20 June 2015).

8. Universal Studios. “Green in Universal.” Available online: http:/ /www.greenisuniversal.com (accessed on 20 June 2015). 
9. Warner Bros. "Sustainability." Available online: https://www.wbcitizenship.com/sustainability/ (accessed on 20 June 2015).

10. Nicky Chambers, Craig Simmons, and Mathis Wackernagel. Sharing Nature's Interest: Ecological Footprints as an Indicator of Sustainability. London: Earthscan, 2000.

11. Mark Lynas. Carbon Counter. London: HarperCollins Publishers, 2007.

12. Carbon Trust. “Carbon Footprinting Guide.” Available online: http://www.carbontrust.com/resources/ guides/carbon-footprinting-and-reporting/carbon-footprinting (accessed on 17 June 2015).

13. Richard Maxwell, and Toby Miller. Greening the Media. New York: Oxford University Press, 2012.

14. US Environmental Protection Agency. “Greenhouse Gas Equivalencies Calculator.” Available online: http: / / www.epa.gov/energy/greenhouse-gas-equivalencies-calculator (accessed on 15 June 2015).

15. Interview with Melanie Dicks, Greenshoot, Managing partner, 4 December 2014.

16. Office for National Statistics. “Greenhouse Gas Emissions-2013." 2015. Available online: http://www.ons. gov.uk/ons/dcp171776_405623.pdf (accessed on 10 June 2015).

17. BBC Arup. "Low Energy Lighting Guide for TELEVISION Productions." 2014. Available online: http: / /downloads.bbc.co.uk/outreach/BBC_LEL_Guidelines.pdf (accessed on 12 May 2015).

18. US Environmental Protection Agency. "Turning Food Waste into Energy at the East Bay Municipal Utility District (EBMUD)." Available online: http:/ / www.epa.gov/region9/waste/features/foodtoenergy/foodwaste.html (accessed on 20 July 2015).

19. The Department for Environment Food and Rural Affairs (DEFRA). "Guidance on Applying the Waste Hierarchy." 2011. Available online: https:/ /www.gov.uk/government/uploads/system/uploads/ attachment_data/file/69403/pb13530-waste-hierarchy-guidance.pdf (accessed on 9 May 2015).

20. Bob Edwards. "With Liberty and Environmental Justice for All: The Emergence and Challenge of Grassroots Environmentalism in the United States." In Ecological Resistance Movements: The Global Emerge of Radical and Popular Environmentalism. Edited by Bron Raymond Taylor. Albany: State University of New York Press, 1995, pp. 35-55.

21. Albert. "Case Studies." Available online: http://wearealbert.org/inspiration/case-studies (accessed on 1 December 2015).

22. Interview with Richard Smith, BBC, Sustainability Manager, 19 November 2014.

23. Greenshoot. "Green Production Training." Available online: http://www.greenshoot.com/training (accessed on 5 June 2015).

24. Interview with Aaron Matthews, British Academy of Film and Television Arts, Industry Sustainability Manager, 6 November 2014.

25. Interview with Tim Williams, Scenery Salvage, Prop Hire, Set Construction, Set Transport and Set Recycling, 4 November 2014.

26. Health and Safety Executive. "Medium Density Fibreboard." Available online: http://www.hse.gov.uk/ woodworking/faq-mdf.htm (accessed on 10 December 2015).

27. Interview with Martin Kern, Scenery Salvage, Prop Hire, Set Construction, Set Transport and Set Recycling, 4 November 2014.

28. Kathy Dhanda, and Laura P. Hartman. “The Ethics of Carbon Neutrality: A Critical Examination of Voluntary Carbon Offset Providers." Journal of Business Ethics 100 (2011): 119-49. [CrossRef]

29. Keith Hyams, and Tina Fawcett. "The Ethics of Carbon Offsetting." Wiley Interdisciplinary Reviews: Climate Change 4 (2013): 91-98. [CrossRef]

30. Maria Mansfield, and Emily Boyd. "Commodifying Carbon: The Ethics of Markets in Nature." Environmental Change Institute Workshop Summary Report. 2007. Available online: http:/ /www.eci.ox.ac.uk/publications / downloads/commodifycarb-report.pdf (accessed on 15 June 2015).

31. Elaine Cohen. "The Race to Rank: The Global 1000 Sustainable Performance Leaders Unveiled." Available online: http:/ /greeneconomypost.com/global-1000-sustainable-performance-leaders-11432.htm (accessed on 10 June 2015).

32. Interview with Frank Horn, British Film Institute, Health \& Safety, Sustainability \& Risk Manager, 21 October 2014.

33. Sony Pictures. “Sony Picture Announces New Sustainability Targets." Available online: http://www. sonypictures.com/corp/press_releases/2013/04_13/041613_sustainability.html (accessed on 20 July 2015). 
34. Brad Stewart. “Green: Film.” 2010. Available online: http://www.mediapost.com/publications/article/ 124872/green-film.html (accessed on 12 June 2015).

35. Robin Murray, and Joseph Heumann. Film and Everyday Eco-Disasters. Lincoln and London: University of Nebraska Press, 2014.

36. Food and Agriculture Organization of the United States. "Tackling Climate Change through Livestock." 2013. Available online: http:/ /www.fao.org/docrep/018/i3437e/i3437e.pdf (accessed on 17 June 2015).

37. Stephen Rust, Salma Monani, and Sean Cubitt, eds. Ecocinema, Theory and Practice. New York: Routledge, 2013.

38. LBB Editorial. “To Infinity and Beyond: The New Age of Editing.” Available online: http://lbbonline.com/ news / to-infinity-and-beyond-the-new-age-of-editing/ (accessed on 20 June 2015).

39. Timothy Luke. "Sustainable Development as a Power/Knowledge System: The Problem of Governmentality." In Greening Environmental Policy: The Politics of a Sustainable Future. Edited by Frank Fischer and Michael Black. London: Paul Chapman Publishing, 1995, pp. 21-32.

40. Fritjof Capra. The Turning Point. New York: Simon and Schuster, 1982.

41. David Ingram. Green Screen: Environmentalism and Hollywood Cinema. Exeter: University of Exeter Press, 2004.

42. Vandana Shiva. Earth Democracy, Justice, Sustainability and Peace. London: Zed Books, 2006.

43. Deloitte. "Landfill Tax Rates." Available online: http://www.ukbudget.com/2015-measures/landfill-taxrates.aspx (accessed on 25 May 2015).

44. Herman Daly. "Economics and Sustainability: In Defense of a Steady-State Economy." In Deep Ecology. Edited by Michael Tobias. San Diego: Avant Books, 1988, pp. 90-100.

45. James O'Connor. Natural Causes: Essays in Ecological Marxism. New York: Guilford Press, 1998.

46. UK Legislation. “Communications Act 2003.” Available online: http://www.legislation.gov.uk/ukpga/ 2003/21 (accessed on 10 December 2015).

47. Arne Naess. "The Shallow and the Deep, Long-Range Ecology Movement, A Summary." Inquiry 16 (1973): 95-100. [CrossRef]

48. Arne Naess. "Identification as a Source of Deep Ecological Attitudes." In Deep Ecology. Edited by Michael Tobias. San Diego: Avant Books, 1988, pp. 256-70.

49. Tim Radford. "How James Lovelock Introduced Gaia to an Unsuspecting World." 2010. Available online: http:/ / www.theguardian.com/science/2010/aug/27/james-lovelock-gaia (accessed on 10 June 2015).

50. Joseph Meeker. “Toward a New Natural Philosophy." In Ecological Consciousness: Essays from the Earth Day X Colloquium (University of Denver, Colorado, 21-24 April 1980). Edited by Robert C. Schultz and J. Donald Hughes. Washington: University Press of America, 1981, pp. 251-64.

51. George Sessions. "Ecological Consciousness and Paradigm Change." In Deep Ecology. Edited by Michael Tobias. San Diego: Avant Books, 1988, pp. 28-44.

(C) 2016 by the author; licensee MDPI, Basel, Switzerland. This article is an open access article distributed under the terms and conditions of the Creative Commons Attribution (CC-BY) license (http://creativecommons.org/licenses/by/4.0/). 